\title{
TRADE MARKS IN EUROPE AND THEIR COMPETITIVENESS
}

\author{
V. Nikolova-Minkova* \\ Department of Social and Economic Sciences, Technical University of Gabrovo, Bulgaria
}

\begin{abstract}
The development of modern business depends to a large extent on consumers and their choice. This is a reason for the companies to compete in creating powerful trademarks through which to attract more consumers and gain a greater market share. Objects of scientific interest in this study are the formed image of the trademarks and the degree of consumer loyalty to them that affects the value of the brands. The purpose of the present study is to explore the leading European brands and to analyze the conditions for developing their competitiveness. In this regard, by applying empirical methods of research (study, comparison and analysis of expert assessments), the paper clarifies the essence of the trademarks and brands and considers the formation of their value based on the image built. The results of the methods used reveal the most valuable for European trademarks, as well as the prerequisites for forming consumer loyalty to them. In conclusion, recommendations are made to increase the competitiveness of brands, which can contribute to increasing consumer loyalty.
\end{abstract}

Key words: trademark, brand, image, consumer loyalty, the value of brands, competitiveness.

\section{INTRODUCTION}

In the modern conditions of the development of markets, facilitated by globalisation and increased competition, it is increasingly difficult for consumers to make the right choice of the desired product. Consumers look not only for diversity in the assortments of traders' products but also seek security when making a purchase. This requires taking into account the effect of the offered products' quality and the creation of strong trademarks that embody the idea of the brand consumption quality.

Before considering the role of the image of trademarks in forming their value, it is necessary to clarify the dilemma about the correct interpretation and use of the terms "trademark" and "brand". Different views of scientists on this issue are known, part of which takes into account a level playing field between the two terms, originating from the

\footnotetext{
*Correspondence to: Ventsislava Nikolova-

Minkova, Department of Social and Economic

Sciences, Technical University of Gabrovo,

Bulgaria. 5300, Gabrovo, Lazar Donkov Str., 3, ventsislava_n@mail.bg,0876444307
}

etymology of the concepts and their interpretation. The modern marketing practice, on the other hand, views a difference between trademark and brand, which is caused by the broader scope of the concept of a brand.

The essence of the trademark in Bulgaria is legally regulated in the Law on Trademarks and Geographical Indicators, and in Art. 9, para. 1 and para. 2 the following definitions of trademark are provided: "(1) A trademark shall be a sign capable of distinguishing the goods or services of one person from those of others and may be represented graphically. Such characters may be words, including names of persons, letters, numbers, drawings, figures, the shape of the commodity or its packaging, a combination of colours, sound marks or any combinations of such characters. (2) A trademark shall be a trade mark, a service mark, a collective mark and a certification mark." (1). The nature of the trademark has been interpreted by a number of marketing professionals. V. Baleva, looking at the definitive differences between trademark and brand, accepts that the brand is " a sign which, by identifying and differentiating the products of one person (or 
persons) from those of another person (or persons), brings an economic benefit to its owner." (2, p. 21). The author adds that "the term brand must now be perceived as broader than the concept of a trademark. The trademark serves the business, it serves the commercial activity (within the meaning of the commercial law). And the concept of a brand can be associated with other objects personality (singer, actor, artist, writer, politician, athlete), non-commercial organization or service, a website" (2, p. 2122). D. Kabakchieva also argued that "the brand is the more general and comprehensive concept of both. The trademark is the most visible and important part of the brand, but it is only one of its many constituent elements. The creation of the trademark underpins the process of brand formation, imposition and development." (3, p. 265). Brand Finance defines brand as the "trademark and associated IP including the word mark and trademark iconography" (4). P. Midova acknowledges that "turning the trademark into a successful brand is a complex and protracted process related to solving multiple problems" (5, p. 50). Analyzing the process of creating and developing the brand, the author adds that it is "not only a trademark consisting of a name, a graphic image, sound symbols of the enterprise or commodity. The term includes:

- a set of characteristics, expectations, associations perceived by consumers (image of the product, brand image).

- a promise of any advantages given by the holder of the brand to the consumers." (5, p. 51).

The brand is a means by which the company, whose ownership it is, can build competitive advantages in the market. As M. Batey asserts "A product becomes a brand when the physical product is augmented by something else-images, symbols, perceptions, feelingsto produce an integral idea greater than the sum of its parts." $(6$, p. 3$)$ The trademark acquires a brand shape only when consumers identify through it the sought-after utility, which in turn manifests itself in the competitiveness of the product.

The usefulness of the brand and the degree to which consumers associate it with the presented high quality of the product that carries it are a prerequisite for shaping the image of the brand. "The properly selected and properly built image is the most effective way to work with mass consciousness. The image reflects the key characteristics to which the mass consciousness responds and can provoke an automatic reaction in the population." (7, p. 25). The image is not permanent, which requires its maintenance with regard to societal attitudes and stereotypes of behavior. The image of the brand, and especially the particular brand, is a prerequisite for consumers to prefer one product over another, regardless of the higher price that often accompanies branded goods. The formed image of the brand in the consumer's mind, the emotions induced in the consumer's consciousness and the experience gained from the possession of the brand, create the subjective value of the brand (8). This brand equity, which is transformed into value for the consumer, materializes in increasing the value of the brand for the company. The authors Raggio and Leone determine the concepts of brand equity and value of the brand by deducing the following definitions: „Brand equity represents what the brand means to the consumer", and "Brand value represents what the brand means to a focal company" (9, p. 381). The relationship between them is indirect and is determined by individual results such as loyalty and brand attachment. Consequently, the equity of the brand influences the value of the brand, but it is not the only factor of impact.

Brand value "is the financial worth of the brand. To determine brand value, businesses need to estimate how much the brand is worth in the market - in other words, how much would someone purchasing the brand pay" (10). The brand value can be defined as "the incremental utility or added value to the product by brand name" (11 - 14). As M. Batey points out "Brands command such huge values because they themselves allow their owners to charge very profitable margins - for products with ingredients as basic as water and syrup." (6, p. 1) These definitions of the nature of the brand value make it one of the leading indicators of the competitiveness of trademarks, so it is necessary to clarify the methodology for its evaluation.

\section{MATERIALS AND METHODS}

Various methods of examining the value of trademarks are known (Figure 1).

Figure 1 presents the different groups of methods for assessing the value of the brand. If the Market methodology and the Income methodology cannot be used, then the Cost methodology is applied. For the purposes of this study, the Royalty relief method (Figure 2), which is part of the Income methodology, 
is considered as a matter of priority. The method determines the value that a company is able to pay to license its brand on the basis of the presumption that it does not own it. The approach includes future revenue that may be
NIKOLOVA-MINKOVA $V$. attributable to a trade mark and the licensing income to be charged for the use of the mark.

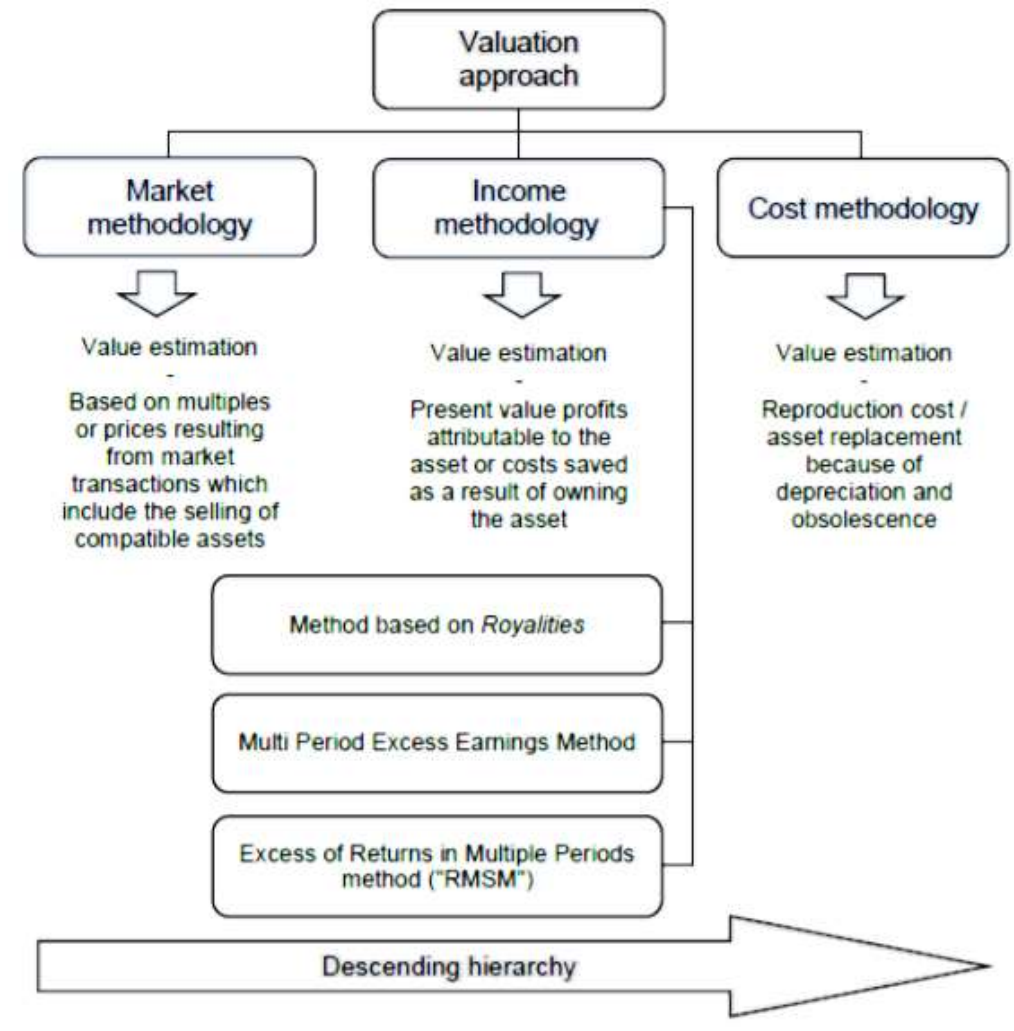

Figure 1. Valuation approach

Source: (14) Martin, G. R., Garcia, C. M. M., Pérez-Hernández, F., Brand Valuation Using Relief Method and Linear Discriminant Analysis, pp. 1 - 32, 2016. http://22financeforum.unizar.es/wpcontent/uploads/2014/11/22financeforum_submission_28.pdf

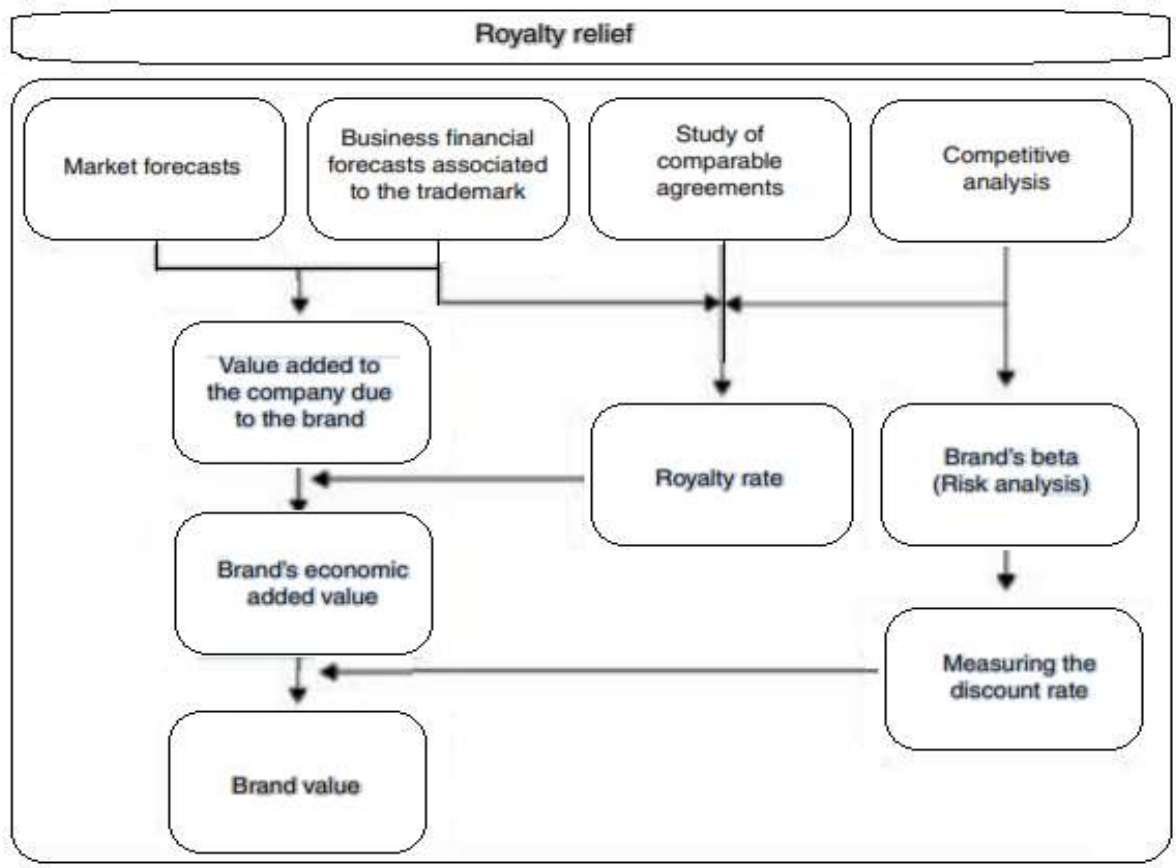

Figure 2. Royalty relief method

Source: (15) Salinas, Valoración de Marcas. Barcelona, España: Deusto, 2007 
The evaluation shall be carried out in the following stages (4):

1. Calculate the strength of the mark on a scale from 0 to 100 , which is based on indicators such as an emotional connection with the trademark, financial performance and sustainability, etc. The assessment is based on the so-called Brand Strength Index.

2. Define the royalty rate range for the relevant brand sectors by comparing it with other licensing agreements.

3. Calculate the royalty rate, by comparing the strength of the trade mark with the royalty rate range in order to obtain the percentage of remuneration.

4. The specific revenue inherent in the trademark shall be determined, which also includes part of the parent company's revenue.

5. Estimates shall be determined on the basis of historical revenue, brand value forecasts and economic growth.

6. The royalty rate shall be applied to estimated revenue, in order to obtain the fee for the use of the mark.

7. Estimated royalties are discounted after tax to net present value, which is the current value of the future income that can be attributed to the brand asset.

The Royalty relief method (Figure 2) is suitable for assessing the value of brands for the following reasons:

- The method is recognized by the tax authorities and courts as it calculates the value of the brand on the basis of transactions documented by third parties.

- The financial information used is publicly available.

- The method is in accordance with ISO 10668 and the International Valuation Authority.

These factors are a prerequisite for the Royalty relief method to be widely applied in the valuation of trademarks, and the subsequent exposition of the study focuses on the value of trademarks in Europe, calculated using the chosen method.

\section{RESULTS}

"In Europe the earliest signs of branding were the medieval guilds' efforts to require craftsmen and craftswomen to put trademarks on their products to protect themselves and consumers against imitation and inferior quality" (6, p. 2). A few centuries later, the European trademarks are part of the most value brands in the whole world.

As can be seen in Figure 3, the top 10 most valuable brands of Europe are presented. The first place in the rankings is taken by the Mercedes-Benz's car giant, whose brand value is $€ 58 \mathrm{bn}$. Second place is for Shell, $€ 42 \mathrm{bn}$, that continues its climb in the rankings despite the falling fuel prices. The reason for this can be found in the strong brand and the commitment to Health, Security, Safety, Environment and Social Performance. Third and fourth positions are also occupied by car giants, such as Volkswagen and BMW. They also climbed by one position, taking in $€ 40.5$ bn (Volkswagen) and $€ 36$.6bn (BMW) worth of the brands. Fifth place is for Deutsche Telekom, which is relegated with three positions - from second to fifth place $(-9.4 \%)$ and registered a reduction in the brand's value of $€ 39,834$ bn (2019) to $€ 36.078 b$. Sixth position is also taken by the automotive industry - Porsche retains its place in the rankings, increasing its value by $21.1 \%$ from $€ 25,271$ bn to $€ 30,619 \mathrm{bn}$. Seventh place for 2020 was taken by Allianz, whose value rose by $12.7 \%$ to $€ 22.427 \mathrm{bn}$. Retaining eighth position from the 2019 rankings, EY, which operates in commercial services, reported a $7 \%$ increase in brand value. Ninth place for 2020 is for BP, which is also climbing two positions, despite the brand being in the oil products sector, which has been struggling since the beginning of 2020 . The brand's value increasing by $7.6 \%$ to $€$ $21,009 \mathrm{bn}$. Tenth position is for Total, the second brand in the rankings with a drop in value by $3.6 \%$ (from 21,691 for 2019 to 20,909 in 2020).

As it is clear from the data referred to in Figure 3, six out of ten brands belong to German companies. This corresponds to the data on the most valuable brands in the world, according to which for $20195.8 \%$ of these brands are owned by German companies.

The change in the value of the top five brands in the 2015-2020 rankings is presented in Figure 4. As the figure shows, Mercedes that rose from $€ 25$ bn in 2015 to $€ 58,728$ bn in 2020 , are the biggest growth. As it becomes clear, for 2015 the brand has the lowest value of the other companies included in the ranking. Shell reported nearly $€ 28$ bn in 2015 and sustainably increased their value until they reached $€ 42$ bn in 2020. It is interesting to see the development of the value of Volkswagen, which from $€ 28 \mathrm{bn}$ in 2015 , in 2016 (€18bn) saw a surge in value, then began to climb the rankings again and regained, and exceeded the value recorded in 2015. BMW, which recorded more than $€ 30 \mathrm{bn}$ in value in 2015 , reported smooth growth over the analysis period, with no sharp declines or highs in value. Deutsche Telekom also achieved nearly €28bn in 2015 and by 2019 the brand value rose, but in 2020 they report a 14\% drop in brand value. 


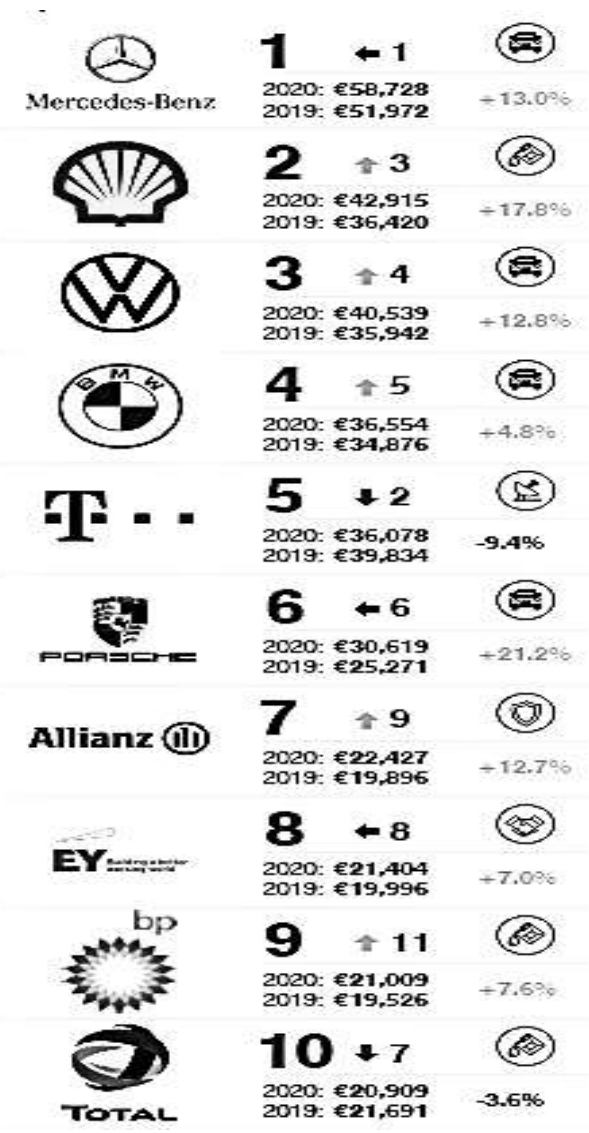

Figure 3. Top 10 Most Valuable Brands

Resource: Brand Finance, Brand Finance Europe 1002020 Report, https://brandirectory.com/rankings/europe-2

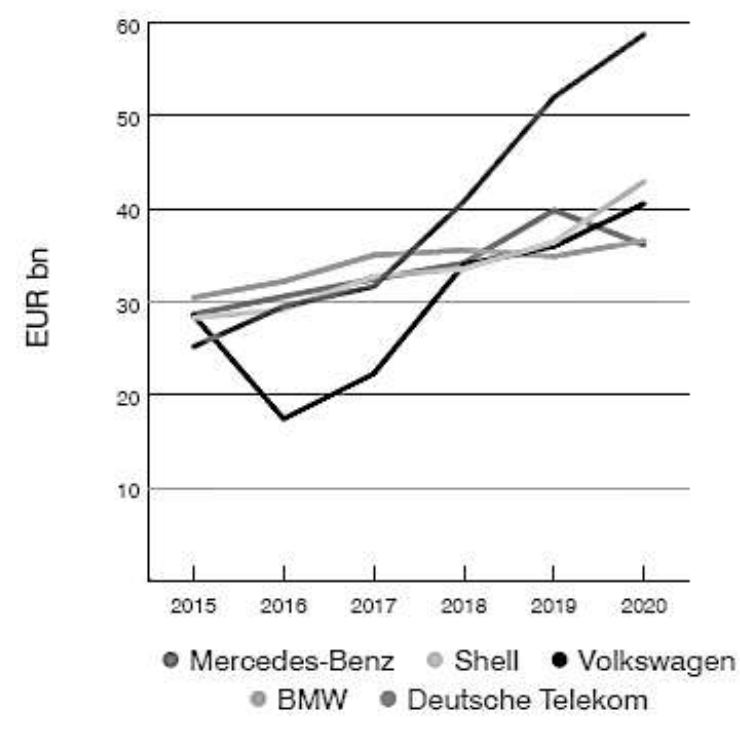

Figure 4. Brand Value of Top 5 Brands

Resource: Brand Finance, Brand Finance Europe 1002020 Report, https://brandirectory.com/rankings/europe-2

Analyzing the biggest rises and declines in brand value (Figure 5), Lidl and Aldi recorded $46.3 \%$ and $43.5 \%$ growth respectively. They are followed by Louis Vuitton $(27,3 \%)$, Volvo $(26,1 \%)$ and some more luxury brands such as GUCCI $(26,1 \%)$, Chanel $(25,2 \%)$, that achieved significant brand value growth despite the tough global economic climate. The opposite is the status of brands such as Philips, O2, Bosch and others, whose value drops. With the biggest drop in value $(24,9 \%)$ is the English Telecom BT, whose position (59th place for 2019) shifts to 91th place for 2020. 


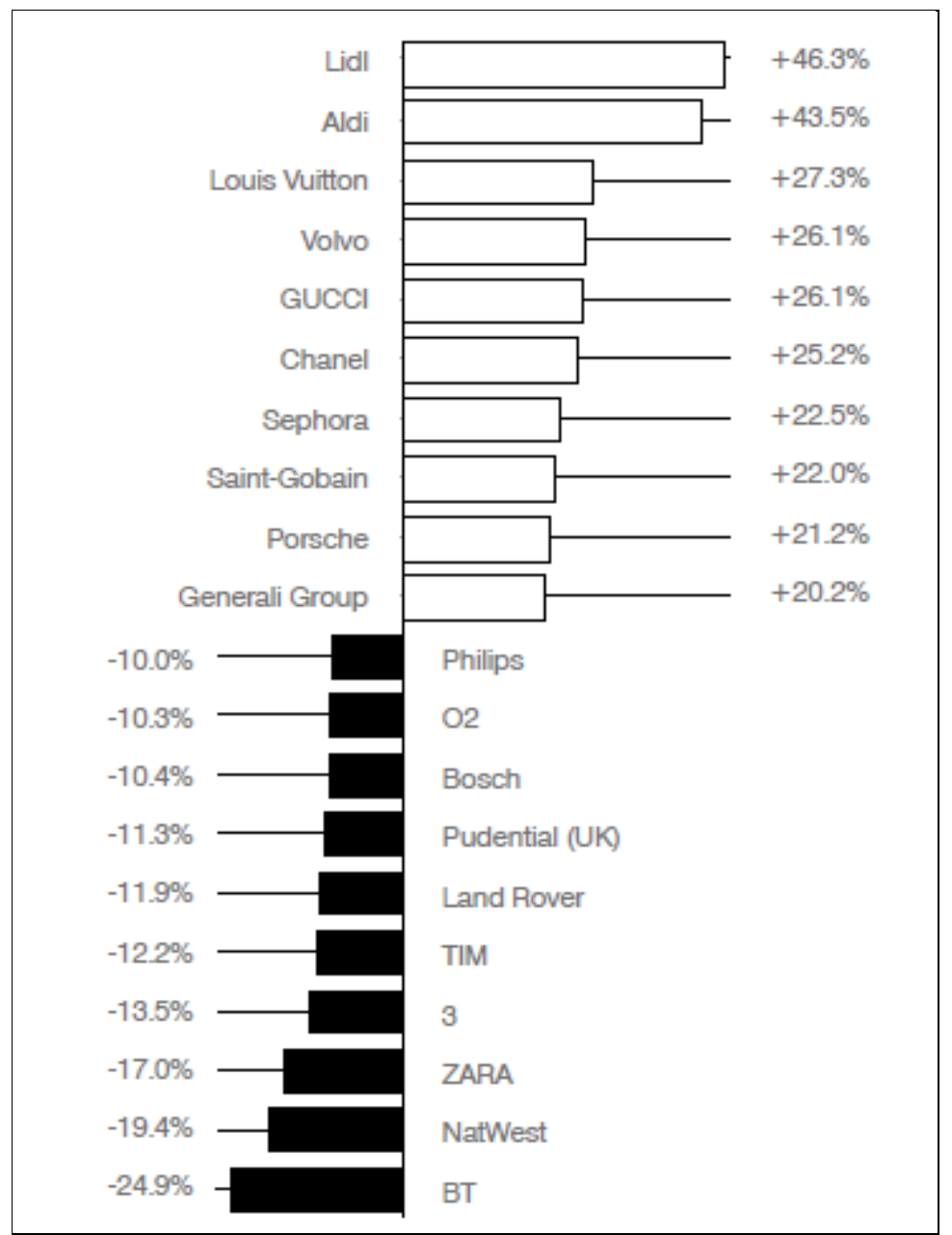

Figure № 5. Brand Value Change 2019 - 2020 (\%)

Resource: Brand Finance, Brand Finance Europe 1002020 Report, https://brandirectory.com/rankings/europe-2

A look at the sectors and countries (Figure 6) with the highest value of the brands included in them shows that the brands in the automotive sector form the largest share $(19,1 \%)$ of all sectors, with the total number of brands in the sector 9 . The banking sector is made up of 16 brands and reports a total of $€ 141,7 \mathrm{bn}$. The

Brand Value by Soctor

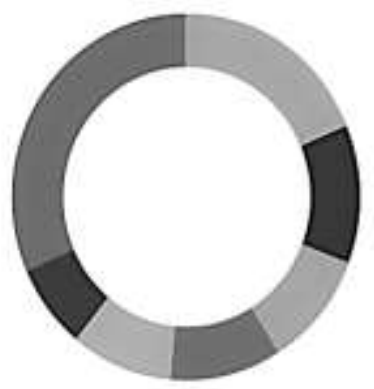

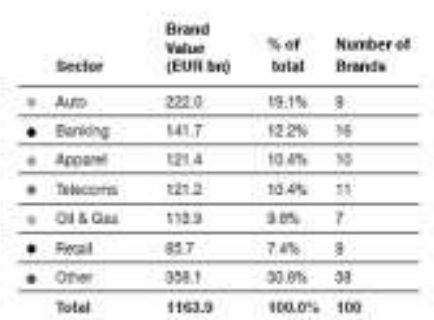

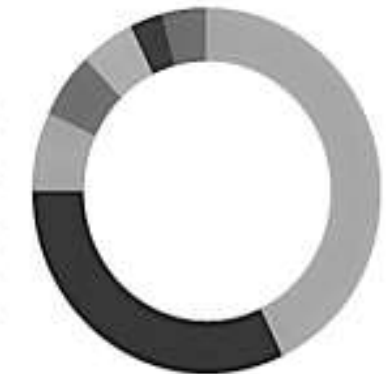

clothing sector is in third place with 10 brands and $€ 121,4 \mathrm{bn}$ worth of brands. The fourth place is for telecoms that form $€ 121,2 \mathrm{bn}$ and include 11 brands. Fifth position is hold by the oil and gas sector, which is composed of 7 brands and 9,8\% share of total. The retail sector is presented by 9 brands and $7,4 \%$ share.

Brand Value by Eeonemy

Figure 6. Brand Value by Sector and by Economy

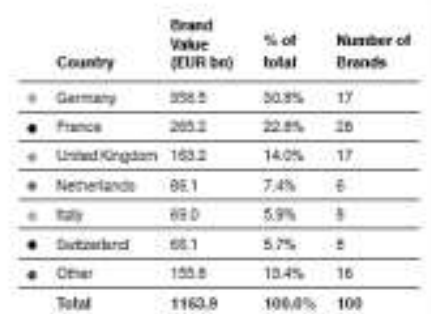

Theth 11698 100.95 109

Resource: Brand Finance, Brand Finance Europe 1002020 Report, https://brandirectory.com/rankings/europe-2

Among the countries whose companies own the brands (Figure 6), Germany is the top performer with $€ 385,5$ bn and a $30,8 \%$ stake made up of 17 brands. The second place is for
France, which, with its 28 brands, achieves a total value of $€ 265,2 \mathrm{bn}$ and a share of $22,8 \%$. Britain has 17 brands with a total value of $€ 163,2 \mathrm{bn}$, while the Netherlands, with just six 
brands, forms $7,4 \%$ of the total. Italy is the next country with eight brands reporting $€ 69,0$ bn, while Switzerland also contributes eight brands valuing a total of $€ 68,1 \mathrm{bn}$.

The data analyzed (Figures 3, 4, 5, 6) make it possible to take into account the influence of the brand, the brand image and the loyalty generated in the consumers on the value of the brand. The brands involved in the ranking, although taking into consideration the influence of the economic factors and the development environment, maintain their value thanks to the loyalty of their customers. In order to strengthen these positions, companies need to pay attention to the needs of their consumers and the changes in their behaviour in line with the changing environment.

\section{CONCLUSIONS}

The above mentioned data on the nature of the concepts of trademark and brand, the clarified specificity of the brand equity and its value, as well as the influence of the brand image upon the formation of the consumers loyalty, make it possible to draw the following conclusions:

1. Consumer loyalty to the brands analysed is due to the policy of the conpanies to preserve consumer attention and interest, as well as to take into account their needs.

2. Turning the value of the brand into value for the consumer is important not only for shaping consumer loyalty, but also for increasing the competitiveness of the brand.

3. The competitiveness of the brand is directly related to its value, as it is a consequence of consumer choice.

In relation to the analysis, the following recommendations can be proposed to increase the competitiveness of the brand:

$>$ companies must link their mission and objectives to consumer needs in order to best meet their demands;

$>$ it is necessary to improve the quality of the products offered by companies, which leads to increased consumer satisfaction;

$>$ focus on implementing innovative methods of servicing and improving the relationship "customer - company" that can increase consumer loyalty.

\section{REFERENCES}

1. Zakon za Markite I Geografskite Oznacheniya,

https://www.lex.bg/index.php/bg/mobile/ldoc/ 2134680576

2. Baleva, V., Targovska marka i/ili brend. Ikonomicheski alternativi, 2: 15-23, 2008.
3. Kabakchieva, D., Branding in Support of the Stable Development of the Region, Sbornik nauchni trudove ot Nauchna konferenciya "Regionalna ikonomika I ustoychivo razvitie" Varna, pp. 263 - 276, 2017.

4. Brand Finance, Brand Valuation Methodology, https://brandirectory.com/methodology

5. Midova, P., Nyakoi problemi na sazdavaneto I razvitieto na brenda. Biznes upravlenie, 1: 49-60, 2006.

6. Batey, M., Brand Meaning, Routledge, New York, 2008.

7. Pavlova, A., Imidzh, reputaciya, brand. Problemi na postmodernostta, tom 5 (1), 2015.

8. Keller, K. L., Strategic Brand Management. Building, Measuring, and Managing Brand Equity, Prentice Hall, Inc, New Jersey, 1995.

9. Raggio, R. D., \& Leone, R. P., The theoretical separation of brand equity and brand value: Managerial implications for strategic planning. Journal of Brand Management, 14(5), 380-395, 2007.

10. Aaker, D., Brand Equity vs. Brand Value: What's the Difference?, September 21, 2016. https://www.prophet.com/2016/09/brandequity-vs-brand-value/)

11. Kamakura, W., Russell, G., Measuring Brand Value with Scanner Data, International Journal of Reasearcher in Marketing, Vol 10 (1), pp. 9-22, 1993;

12.Park, C. S., Srinivasan, V., A syrvey-based method for measuring and understanding brand equity and its extendibility, Journal of Marketing Research, Vol. 31, pp. 271 - 288, 1994.

13. Bigné, E., Borredá, A., Miquel, M. J., El valor del establecimiento y su relación con la imagen de marca privada: efecto moderador del conocimiento de la marca privada como oferta propia del establecimiento. Revista Europea de Dirección y Economía de la Empresa, 22(1), 1-10. 2013;

14. Martin, G. R., Garcia, C. M. M., PérezHernández, F., Brand Valuation Using Relief Method and Linear Discriminant Analysis, pp. $1 \quad-\quad 32, \quad 2016$. http://22financeforum.unizar.es/wpcontent/uploads/2014/11/22financeforum_sub mission_28.pdf

15. Salinas, G., Valoración de Marcas. Barcelona, España: Deusto, 2007.

16. Brand Finance, Brand Finance Europe 100 2020 Report, https://brandirectory.com/rankings/europe-2 
NIKOLOVA-MINKOVA V. 